\title{
Možnosti využití metody eyetrackingu ve výzkumu kompetencí historického myšlení na příkladu analýzy ikonografického pramene - karikatury ${ }^{1}$
}

\author{
Denisa Labischová
}

\author{
Ostravská univerzita v Ostravě, Pedagogická fakulta, Katedra výchovy k občanství
}

\begin{abstract}
Redakci zasláno 7. 12. 2014 / upravená verze obdržena 26. 2. 2015 / k uveřejnění přijato
\end{abstract} 2. 3.2015

\begin{abstract}
Abstrakt: Empirická studie pojednává o perspektivách využití metody eyetrackingu, založené na sledování očních pohybů při percepci verbálního a ikonického textu, a přináší výsledky předvýzkumu z roku 2014, jehož cílem bylo ověřit výzkumný nástroj pro zkoumání vlivu konkrétního způsobu strukturace analýzy historické karikatury na kvalitu její interpretace respondenty. V první kapitole jsou vymezena teoretická východiska (význam historických pramenů v procesu rozvíjení kompetencí historického myšlení) a jsou zde uvedeny možnosti uplatnění eyetrackingu v pedagogickém výzkumu. Ve druhé kapitole jsou popsány použité metody sběru a zpracování dat. Zvolen byl smíšený výzkumný přístup, zahrnující analýzu audiozáznamů slovních odpovědí studentů a statistických i vizualizovaných dat získaných elektronickým měřením. Testováno bylo 23 studentů učitelství z Moravskoslezského kraje. Ve třetí kapitole jsou prezentována výzkumná zjištění - návrh kategoriálního systému pro interpretaci karikatury, vizualizace dat v podobě heatmap, gaze opacity map a gaze plots a nejvýznamnější kvantitativní data (rozdíly v četnosti a délce očních fixací v průběhu testu). Předvýzkum ukázal, že eyetracking může poskytnout jinými metodami obtížně zjistitelné informace o percepčních strategiích uplatňovaných při interpretaci textu. Výsledky naznačují, že v př́padě didakticky strukturované analýzy historické karikatury dosahují respondenti vyšší úrovně interpretace než při analýze nestrukturované, kdy se slovní odpovědi omezují převážně na zobrazené osobnosti a jsou opomíjeny důležité symboly, obrazové kódy i širší historický kontext.
\end{abstract}

Klíčová slova: didaktika dějepisu, empirický výzkum, kompetence historického myšlení, analýza historické karikatury, metoda eyetrackingu, analýza audiozáznamů

1 Článek je výstupem Institucionálního rozvojového plánu Ostravské univerzity - Pedagogické fakulty pro rok 2014, členky výzkumného týmu č. 5: Denisa Labischová, Ivana Gejgušová a Danuše Sztablová. 
V české didaktice dějepisu se odborný zájem až dosud upínal především k postižení komplexního fenoménu historického vědomí, $\mathrm{k}$ analýzám kurikulárních dokumentů $\mathrm{v}$ diachronním náhledu, $\mathrm{k}$ výzkumu českých i zahraničních učebnic dějepisu z různých hledisek (evropská dimenze, genderová korektnost, didaktická vybavenost) a k vybraným problémům spojeným s reálnou podobou výuky dějepisu na školách, např. k uplatňování vyučovacích forem a metod, práci s médii či historickými prameny. $\mathrm{V}$ dosavadních výzkumech dominoval kvantitativní výzkumný přístup (longitudinální šetření s využitím techniky dotazníku), méně již kvalitativní (nekvantitativní obsahové analýzy, hloubkové rozhovory) či smíšený (kombinace focus groups/dotazník).

Stále jen velmi pozvolna se badatelská pozornost obrací k procesu učení $\mathrm{v}$ rámci dějepisného vyučování, především z důvodu absence relevantního metodologického ukotvení. Inspirace lze alespoň částečně čerpat ze zahraniční oborové didaktiky a z oblasti výzkumu pedagogického. Cílem této studie je naznačit nové možnosti aplikace výzkumné metody eyetrackingu, která se $\mathrm{v}$ (nejen české) didaktice dějepisu dosud prakticky nepoužívala, a prezentovat prvotní výsledky z výzkumu vizuální percepce ikonického textu.

\section{Teoreticko-metodologický rámec}

\subsection{Význam karikatury v procesu historického učení}

V souladu se zahraničními trendy (vycházejícími zejména z německého prostředí) klade česká didaktika dějepisu v posledním desetiletí důraz nikoliv na pouhou reprodukci určitého penza historických vědomostí, nýbrž především na rozvíjení kompetencí historického myšleni ${ }^{2} \mathrm{v}$ dějepisném vyučování (Schreiber et al., 2006; Körber, Schreiber, \& Schöner, 2007; Gläser \& Becher, 2012). Tento koncept čerpá z kognitivně konstruktivistické didaktiky a je založen na aktivní mentální konstrukci a reprezentaci poznatkových struktur v procesu historického učení ${ }^{3}$ (Lange, 2011; Spieß, 2014). Kompetence historického myšlení zahrnují komplex znalostí a dovedností, na jejichž základě se formuje a kultivuje historické vědomí žáků a studentů, a jsou vztaženy k pojmům porozumění, utváření smyslu, rekonstrukce a dekonstrukce (Schreiber, 2008).

\footnotetext{
Pojem je přejat z německé didaktiky dějepisu - Kompetenzen historischen Denkens.
}

3 Ang. Historical Learning, něm. historisches Lernen. 
Do souboru těchto specifických kompetencí patří mimo jiné způsobilost analyzovat a interpretovat historické prameny nejrůznější provenience, přičemž v souvislosti s mohutnou „vizualizací“ současného světa nabývají na významu prameny ikonografické - obrazy, fotografie či karikatury (Talkenberger, 1994; Henke-Bockschatz, 2000; Sauer, 2000; Pandel, Becher, \& Schneider, 2002; Kratochvíl, 2004; Labischová, 2008, 2009; Land \& Pandel, 2008; Handro \& Schönemann, 2011). Právě poslední jmenované umožňují svou povahou (reprezentují určitý názor, úhel pohledu, hodnotí společenskou situaci) všestranně uplatňovat princip multiperspektivity, prosazující se v teorii dějepisného vyučování již řadu let (Stradling, 2004). Badatelsky orientovaná je dnes již většina zahraničních učebnic dějepisu, kde je práci s historickými prameny, včetně ikonografických, věnována mimořádná pozornost (Labischová, 2014).

Východiskem pro začlenění svébytného žánru karikatury do dějepisného vyučování se stala především Panofského (1978) třístupňová strukturace obrazové analýzy, rozlišující předikonografické pozorování obrazu, ikonografickou obrazovou analýzu a ikonologickou interpretaci. Obecně akceptován je Pandelův interpretační model, směřující $\mathrm{k}$ době vzniku karikatury, postižení historické situace, rozlišení použitých výrazových prostředků a identifikaci ústředních tendencí výpovědi a intencí karikaturisty (Pandel \& Schneider, 2005). Jakousi syntézu dosavadních teoretických konceptů pak představuje nejnovější Schnakenbergův analyticko-syntetický model (Schnakenberg, 2012).

Zejména v zahraničí, ale také v české oborové didaktice byly realizovány empirické studie, které zkoumaly nejrůznější aspekty využití karikatury ve výuce dějepisu. V roce 2007 publikovali Wolfrum a Sauer výsledky smíšeného výzkumu, zaměřeného na proces kritické reflexe karikatur žáky (včetně žákovských postojů k práci s tímto specifickým historickým pramenem); v témže roce dospěl Bernhardt k závěru, že žáci nepostupují při analýze karikatury systematicky, nýbrž nahodile, ignorují podstatné detaily, nepopisují kontext, ale jen dílčí vztahy, chápou sice historický původ karikatury, avšak bez hlubšího porozumění (cit. podle Schnakenberg, 2012, s. 101).

Gracová $(2008,2012)$ se zaměřovala na zařazení analýzy a interpretace ikonického textu (fotografií a karikatur) na českých základních a středních školách v opakovaných kvantitativních výzkumech, vždy v rámci zkoumání realizovaného dějepisného kurikula (aktuální podoby výuky dějepisu). 
Konstatuje, že čeští žáci rozpoznávají nejsnadněji individuální personální karikatury zobrazující české historické osobnosti z oblasti politiky a většinou opomíjejí použitou symboliku i širší historický kontext. Příčinu spařuje především $v$ tom, že obrazové prameny plní v dějepise obvykle pouze ilustrativní funkci a konkrétně historické karikatury využívá při prezentaci učiva pravidelně jen $8 \%$ učitelů (Gracová, 2012).

Dosud je k dispozici jen málo relevantních výzkumných dat, která by potvrzovala pozitivní souvislost didakticky řízené analýzy karikatur (a dalších ikonografických pramenů) a reálné kvalitativní úrovně jejich „čtení“ a porozumění žáky a studenty různých typů škol. Vzhledem k tomu, že interpretace obrazu je úzce spojena s percepčními procesy (ke vztahu vnímání a porozumění blíže Sauer, 2013), zaměřili jsme se právě na percepční strategie žáků a studentů. Jednu z cest, jak do složitého procesu vizuální percepce „nahlédnout", představuje výzkumná metoda eyetracking, založená na pozorování očních pohybů.

\subsection{Eyetracking jako výzkumná metoda a možnosti jejího uplatnění}

Zkoumání motorické aktivity očí se stalo předmětem odborného zájmu již ve druhé polovině 19. století, kdy francouzský lékař Javal (1878) uskutečnil v oftalmologické laboratoři první pokusy se svými pacienty s různými typy očních vad. Sledoval také proces čtení a vypozoroval tři základní druhy samovolných očních pohybů - fixace, sakády a regrese, resp. zpětné pohledy k určitým místům textu (cit. podle Just \& Carpenter, 1976).

Hlavní funkcí očních pohybů je podle Jošta (2009, s. 12) „umístit a udržet obraz objektu, který pozorujeme a který dopadá na sítnici, v místě nejostřejšího vidění, tj. na fovei (žluté skvrně sítnice)“. Autor rozlišuje oční pohyby fixační, sakadické, plynulé sledovací a vestibulárně-optokinetické. Zatímco sakády představují nejrychlejší změny pohledu a zachycují rychlé pohyby objektu ve vizuálním poli s cílem udržet co nejostřejší obraz, plynulé sledovací oční pohyby pozorují objekty kontinuálně, bez rychlých skoků a fixací. Vedle fixací a sakád se při čtení aktivují také tzv. vergence, díky nimž nevidíme text dvojmo, ale jako jednotný obraz (Jošt, 2009).

Výzkumná metoda eyetracking je založena na zkoumání mentálních procesů percepce a kognice, tedy na vnímání objektu a jeho uchopení poznávacími mechanismy jedince (Duchowski, 2007). Uplatnila se po druhé světové válce nejprve v oblasti vojenství ve vývoji armádních technologií k zaměřování 
vojenských cílů či při přistávání pilotů, postupně pronikala do výzkumu v neurovědách, v psychologii a psychiatrii (Bartfai et al., 1985; Franco-Watkins \& Johnson, 2011), v informačních technologiích se zaměřením na studie použitelnosti, uživatelsky vstřícnou tvorbu webových stránek a počítačové hry (Jacob \& Karn, 2003; Majaranta et al., 2012), dále v aplikaci na sféru automobilismu (Darrelmann, Richard, \& Schwartz, 2010), reklamy a marketingu (Silberer, 2005; Klimeš, 2008) či při hodnocení geografických map (Popelka, Brychtová, \& Voženílek, 2012). Mnohostranné využití může metoda nalézt též v tělesné výchově a sportu, kde lze sledovat pohyb očí v míčových hrách nebo při střelbě.

Velký potenciál pro uplatnění má eyetracking přirozeně rovněž $\mathrm{v}$ pedagogickém a oborově didaktickém výzkumu. Lai et al. (2013) vymezili v přehledu výzkumných studií zabývajících se procesem učení s využitím metody eyetrackingu, realizovaných v letech 2000-2012, nejčastěji zkoumané fenomény: percepci, sociální kognici, reprezentaci významu, jazyk, zdůvodňování, utváření pojmů a učební strategie.

Asi nejvíce dosavadních empirických výzkumů se týká procesu čtení, kolísání pozornosti a sledování pochopení zadaných úkolů. Beers et al. (2010) zjistili na základě měření pomocí eyetrackeru významnou závislost kvality písemné kompozice adolescentů na preferenci statarického nebo globálního čtení vlastního textu během psaní. Práce participantů inklinujících ke statarickému čtení byly vyhodnoceny jako kvalitnější a promyšlenější.

Knight a Horsley (2014) vypracovali metodiku pro výzkum procesu čtení a použili ji ve svém kvalitativním výzkumu vycházejícím z designu zakotvené teorie na vzorku patnácti žáků ve věku 12-13 let. Zjistili, že zdatnější čtenáři přecházeli při řešení učebních úloh k porozumění textu kontinuálně a konzistentně od zadaných otázek k příslušným pasážím, v nichž byla obsažena odpověd'. Naproti tomu žáci dosahující při čtení horšího výkonu mnohdy nepřečetli celý text ani všechny alternativy odpovědí, často měli tendenci úkol bud' předčasně vzdát, nebo četli lineárně zleva doprava a odshora dolů bez selektivního zaměření na klíčová slova.

Podstatná část dosud uskutečněných empirických výzkumů se týká také učení s využitím ICT. Jamet (2014) sledoval zaměření pozornosti respondentů na barevně zvýrazněné prvky textu při využívání multimediálních výukových materiálů. Persaud a Eliot (2014) se věnovali e-learningu, zkoumali autoregulační mechanismy při on-line učení a dospěli ke zjištění, že pro 
seberegulaci jsou podstatné učební cíle, které určují aktivitu studujících. Autoři dále rozlišují dva typy studentů - jedni se při produkci textu dívali převážně do monitoru, druzí na klávesnici. U participantů, kteří vždy při pohledu na monitor přestali psát, se přerušily také kognitivní a metakognitivní procesy, na rozdíl od těch, kteří psali automaticky bez sledování klávesnice.

Rozvíjí se též bádání v oblasti didaktiky přírodních věd. Błasiak et al. (2013) prováděli výzkumy v didaktice fyziky a zjištovali, jak se liší percepční strategie při řešení učebních úloh mezi úspěšnějšími a méně úspěšnými žáky. Zjistili, že úspěšnější žáci četli mnohem pozorněji zadání úlohy, oproti tomu žáci s horšími výsledky se častěji opakovaně vraceli k již prohlédnutým částem obrazového pole.

Také v českém pedagogickém výzkumu se v současnosti hledají cesty pro využití této metody. Jošt $(2009,2011)$ zkoumal poruchy čtení (dyslexii) a jejich projevy ve specifické trajektorii očních pohybů. Červenková et al. (2014) zjištovali prostřednictvím technologie eyetrackingu vztah pohybu očí a exekutivních funkcí žáků nižšího stupně víceletého gymnázia při řešení úloh $\mathrm{k}$ porozumění verbálnímu a ikonickému textu z vybrané učebnice dějepisu a dospěli k závěru, že žáci neumějí efektivně využívat obrazový materiál a také při čtení verbálního textu pracují obvykle mechanicky bez hlubšího porozumění - např́klad opakovaně čtou pasáže obsahově nesouvisející se zadanými úlohami. Autoři identifikovali ve sledovaném souboru žáků dva základní typy čtenářů, jednak tzv. skenery, kteří věnovali obrazu, výkladovému textu i textu doprovodnému rovnoměrnou pozornost a vybírali vždy sémantické jádro informace (to podstatné), a tzv. čtenáře, kteří přistupovali ke čtení velmi důsledně a četli dlouho a podrobně. „Čtenáři“ dle analýzy získaných dat řešili kognitivně náročnější úlohy s většími obtížemi než „skeneři“. Metelková Svobodová (2014) se zaměřila na vybrané aspekty počátečního čtenářství a na rozdíly ve strategiích čtení osvojených žáky při výuce analyticko-syntetickou a genetickou metodou čtení, které budou sledovány v longitudinálním výzkumu.

Při zkoumání očních pohybů se v současnosti nejčastěji používá elektronický přístroj eyetracker (oční kamera). Data získaná jeho prostřednictvím se generují jednak formou statistických údajů vyjadřujících frekvenci a délku jednotlivých fixací na jednotlivé přesně vymezené objekty a oblasti pozorovaného obrazu, jednak ve vizualizované podobě, přičemž nejčastěji se jedná o následující tři formy zobrazení dat (Popelka, Brychtová, \& Voženílek, 2012): 
Heatmapa: fixační mapa sloužící k vizualizaci kvantitativních charakteristik pohledu s využitím barevné škály (červeně jsou vyznačena místa s nejvyšší intenzitou - tedy četností a délkou fixací, škála postupně přechází do oranžové, žluté, zelené a modré).

Gaze plot: trajektorie jednotlivých sakád spojující pozice fixací (pořadí jednotlivých fixací je označeno čísly), zobrazená na sledovaném obraze v podobě různě velkých kruhů, jejichž velikost závisí na intenzitě fixací. Nevýhodou je, že při větším množství dat se kruhy překrývají, vizualizace je nepřehledná, což znemožňuje interpretaci dat.

Gaze replay: videozáznam očních pohybů, tedy dynamický záznam trajektorie pohledu v závislosti na čase, kombinuje se obvykle s hlasitým myšlením (thinking aloud).

Vedle výše uvedených způsobů zobrazení se užívá také tzv. gaze opacity mapa, zachycující míru transparentnosti sledovaného objektu při zkoumání fixačního pole v průběhu percepce. Je jakýmsi opakem heatmapy - světle jsou zobrazována ta místa, kde byl zaznamenán nejvyšší počet a délka fixací, naopak tmavě místa, kam pohled směřoval jen zř́́dka nebo vůbec (blíže Špakov \& Miniotas, 2007). Gaze opacity tak ukazuje nejčastěji vnímaná a naopak „slepá“ místa v obrazovém poli.

\section{Předvýzkum}

\subsection{Cíle a výzkumné otázky}

Výzkum psychodidaktických aspektů vizuální percepce edukačního textu je pojat jako důležitý předpoklad zamýšleného komparativního výzkumu učebnic pro základní a střední školy z hlediska efektivity didaktického zpracování verbální a ikonické složky textu. Základní výzkumná otázka zní:

Jak didakticky strukturovaný soubor otázek (konkrétní interpretační model) ovlivňuje percepční strategie žáků/studentů a následné porozumění verbálnímu a ikonickému textu? ${ }^{4}$

Cílem prezentovaného předvýzkumu bylo především ověřit a upravit výzkumný nástroj pro výzkum vlivu didaktické strukturace analýzy historické karikatury na množství a kvalitu informací produkovaných žáky/studenty v průběhu její interpretace.

4 V rámci výzkumu byla vedle historické karikatury zkoumána také percepce uměleckého textu - ukázka lyrické poezie z tvorby Adolfa Heyduka (publikováno in Gejgušová, 2014) a reprodukce kubistického výtvarného díla. 


\subsection{Metody sběru a zpracování dat}

Pro sběr a analýzu dat byl zvolen smíšený výzkumný přístup, kombinující kvalitativní a kvantitativní postupy. Výzkumný nástroj představoval ucelený počítačový test, tvořený didakticky strukturovaným souborem otázek, řídících analýzu a interpretaci historické karikatury s využitím přístroje Eye Tracker Tobii TX300 a softwaru Tobii Studio, zahrnující také audiozáznam slovních odpovědí v průběhu testování.

Základní složku výzkumného testu tvořila historická karikatura britského karikaturisty a kritika politiky appeasementu Davida Lowa (1891-1963). Karikatura znázorňuje jednání Adolfa Hitlera, Neville Chamberlaina, Édouarda Daladiera a Benita Mussoliniho vedoucí k podpisu mnichovské dohody dne 29. 9. 1938, která byla o den později otištěna v britském deníku Evening Standard (obrázek 1).

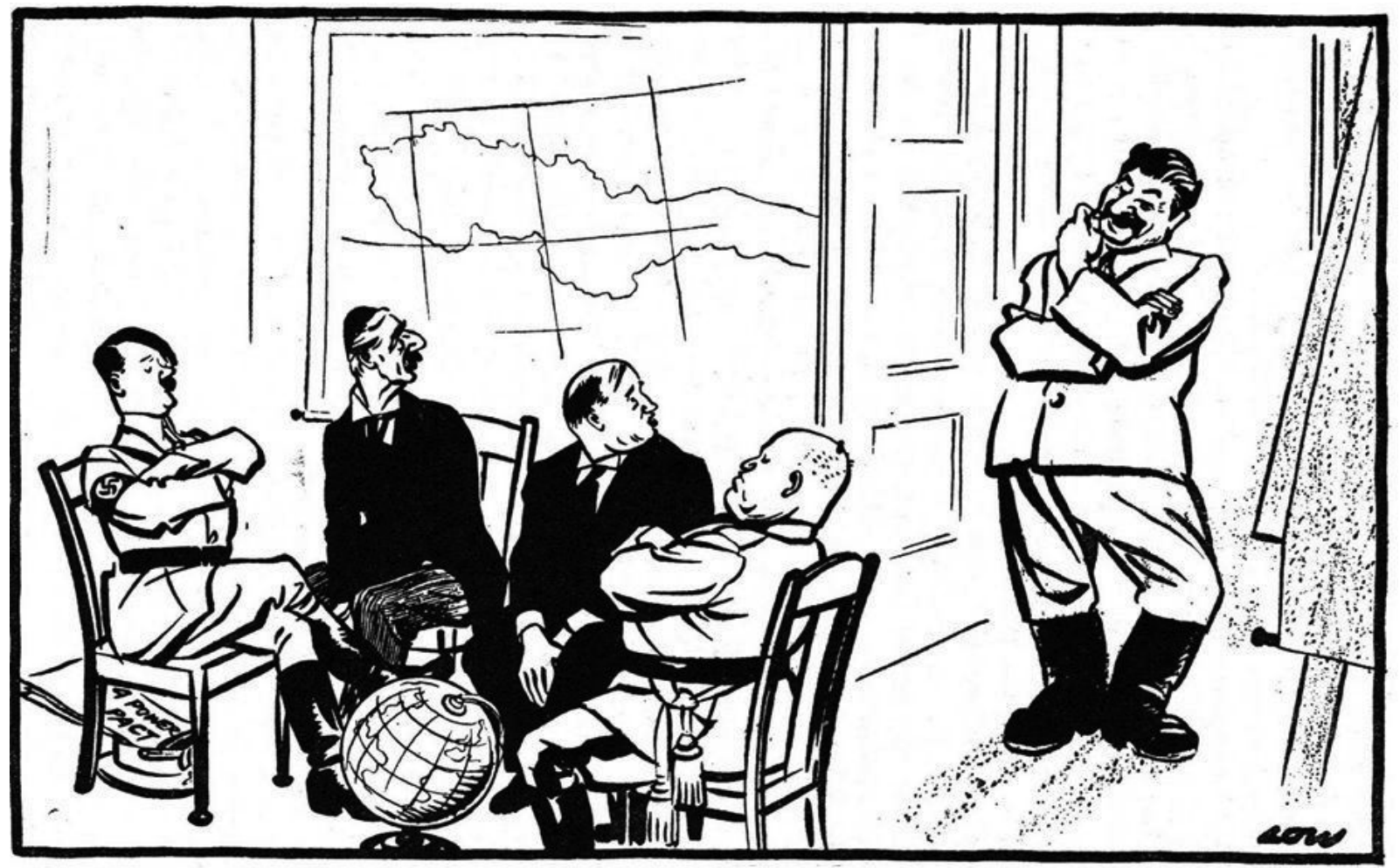

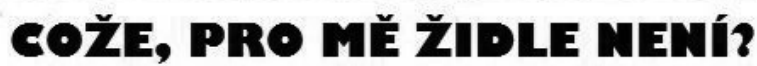

Obrázek 1. Karikatura Davida Lowa z roku $1938 .^{5}$

5 Karikatura dostupná z http://www.cartoons.ac.uk/record/LSE2568. 
Výběr této konkrétní karikatury byl dán několika důvody:

- karikatura zobrazuje jednu z klíčových událostí československých dějin, která by měla být známa většině žáků a studentů;

- karikatura obsahuje snadno dešifrovatelné symboly (hákový kříž, mapa první Československé republiky, text Paktu čtyř z roku 1933, glóbus, uniformy, nonverbální komunikační znaky - dominantní a podřízený postoj účastníků jednání, postava stojící mimo jednání);

- karikatura je doporučována oborovými didaktiky pro využití ve výuce, byla zařazena i do některých zahraničních učebnic, českých metodických příruček (Gracová, Drahošová, \& Labisch, 2009) a figurovala také v testech koncipovaných v rámci dřívějších empirických výzkumů (Gracová, 2008, 2012).

Úkolem účastníků výzkumu bylo:

- pozorovat karikaturu a pozorně sledovat otázky zobrazují se postupně na monitoru počítače (při stálém zobrazení dané karikatury);

- odpovědi na dané otázky formulovat nahlas (čas vymezený pro jednu otázku nebyl nijak omezen).

Soubor otázek zahrnoval nejprve 13 (červen 2014), po úpravě testu na základě zkušeností a výsledků první etapy měření pak 11 (říjen 2014) otázek:

\section{Vysvětlete následující karikaturu.}

Pro následnou komparaci efektivity nestrukturované a strukturované analýzy byla nejprve formulována didakticky nepř́liš vhodná otázka, která však mnohdy v praxi dějepisného vyučování na sekundárním stupni vzdělávání převládá (Gracová, 2008, 2012). Formulace je př́liš obecná a analýzu karikatury neřídí, proto jsme předpokládali, že při odpovědi na ni bude percepce karikatury spíše povrchní, testovaní nebudou detailně rozlišovat jednotlivé symboly a obrazové kódy a také slovní interpretace karikatury bude probíhat s obtížemi.

\section{Vyjmenujte symboly použité na karikatuře.}

Druhá otázka již otevírá blok deseti promyšlených kroků strukturované analýzy. Je zaměřená na fázi detailního pozorování obrazu a na rozeznávání použitých obrazových a verbálních kódů. 


\section{Které osobnosti karikatura zachycuje a jaké politické funkce zastávají?}

Otázka se vztahuje ke kognitivní dimenzi analýzy, žáci identifikují jednotlivé historické osobnosti (aktéry zobrazené události) a jsou nuceni prokázat základní znalosti (jmenovat politické funkce představitelů zúčastněných zemí).

\section{Co vyjadřuje oděv jednotlivých postav?}

Tato otázka doplňuje předchozí a směřuje k postižení vztahu symbolů uniforma - diktátor vs. společenský oblek - představitel západní demokracie. Vedle snadno rozlišitelné Hitlerovy nacistické uniformy je možno rozpoznat také typický oblek anglického gentlemana či Mussoliniho uniformu s důstojnickou šerpou zakončenou střapci.

\section{Jaké pocity vyjadřují pozice, v nichž jsou postavy zobrazeny?}

Dalším krokem bylo systematické pozorování propojené se znalostmi a osobními zkušenostmi (a na jejich základě utvářenými prekoncepty) z oblasti nonverbální komunikace. Karikaturista uplatnil širokou škálu nonverbálních projevů (založené ruce, schoulená záda, nepřístupný výraz tváře atd.) pro zachycení aktuální mezinárodněpolitické pozice jednajících, čímž ve zkratce vystihl historický kontext události, což by měli testovaní v průběhu interpretace také reflektovat.

\section{Proč postava vpravo nesedí?}

Otázka vede žáka k pochopení hlubších mezinárodněpolitických souvislostí a adekvátnímu objasnění pozice Sovětského svazu - Stalin si mne kníry a spokojeně se usmívá (ví, že v dalším politickém vývoji sehraje významnou roli), Chamberlain a Daladier se k němu obracejí. Zřetelný je jeho dominantní sebevědomý postoj v kontrastu s podřízeným postojem představitelů západních mocností vyjadřujícím pasivitu politiky appeasementu. V průběhu analýzy jsme sledovali také propojení percepce ikonické složky s verbálním textem.

\section{Proč je na karikatuře glóbus?}

Zaměření na jeden $\mathrm{z}$ podstatných symbolů karikatury je důležité pro vystižení mezinárodních souvislostí a globálního významu prezentované události (v Mnichově se sice jednalo „pouze“ o československém pohraničí se silným zastoupením německého obyvatelstva, šlo tedy o relativně malý region ve střední Evropě, výsledek jednání však potvrdil slabost 
politiky appeasementu a vedl $\mathrm{k}$ dalšímu porušování mezinárodních úmluv ze strany Německa).

\section{Kterým detailům nerozumíte?}

Tato otázka byla záměrně začleněna až do poslední části testování. Předpokládali jsme, že v průběhu předchozí analýzy si již testovaní celou karikaturu důkladně prohlédli, přesto mohli narazit na symboly a ikonické kódy, které jsou jim nesrozumitelné, které bud' nedokáží vůbec identifikovat, nebo jim není zřejmý jejich smysl. Zde se otevírá prostor pro podporu ze strany učitele (scaffolding), který může dovysvětlit obtížné detaily a souvislosti.

\section{Ke které historické události se karikatura vztahuje?}

V souladu s obecnými interpretačními modely pro analýzu karikatur není shrnutí hlavního tématu (syntéza) zařazeno $\mathrm{v}$ úvodu interpretace, nýbrž následuje až po důkladném popisu a analýze jednotlivostí (symbolů a jejich významu).

\section{Proč zde není zástupce ČSR?}

Otázka předpokládá znalost celé historické situace a vztahuje se $\mathrm{k}$ pochopení souvislostí, které nelze z karikatury přímo vyčíst či odhadnout. Jejím smyslem je dovysvětlení okolností mnichovské krize, př́ípadně také postojů československých představitelů (především Edvarda Beneše) a veřejnosti a naznačení dalšího vývoje v Československu.

\section{Jaký postoj k situaci karikaturista zastává?}

Smyslem zařazení úkolu je interpretace autorova záměru, tedy postižení hlavní intence karikaturisty, jeho postoje, hodnocení dané události a vystižení perspektivy, z jaké autor na událost nahlíží (vyjádření ne/souhlasu, distance, sympatizování s určitou stranou konfliktu, zesměšnění protivníka apod.).

Pro analýzu získaných dat byly uplatněny následující výzkumné techniky:

1. Záznamy pořízené elektronickým přístrojem eyetracker byly vyhodnoceny jednak v podobě grafického zobrazení výsledků měření (heatmapy, gaze plots, gaze opacity mapy, gaze replay), jednak na základě statistických dat a výpočtů (průměrná frekvence a délka jednotlivých očních fixací). 
2. Slovní odpovědi testovaných studentů byly zaznamenány audiosystémem, byla realizována jejich následná doslovná transkripce a odpovědi byly vyhodnoceny formou otevřeného a axiálního kódování ${ }^{6}$, kategorizace a částečné kvantifikace dat.

\subsection{Zkoumaný soubor a organizace výzkumu}

Vzhledem k tomu, že se jednalo o předvýzkum k rozsáhlejšímu empirickému výzkumu rozšířenému o soubor žáků základních a středních škol, byli v první fázi osloveni a testováni pouze vysokoškolští studenti Pedagogické fakulty Ostravské univerzity v Ostravě, kteří se k participaci na měření dobrovolně přihlásili.

Vedle samotného testování pro nás byla totiž podstatná také reflexe průběhu měření (organizační podmínky, formulace otázek, jejich množství, řazení, jednoznačnost, volba konkrétní karikatury), která bude podkladem pro úpravu a optimalizaci testu v další fázi projektu. Právě tuto reflexi nám mohly poskytnout rozhovory se studenty učitelských oborů (především 1. ročníku navazujícího magisterského studia), kteř́ již disponují jistými znalostmi z oblasti pedagogiky, psychologie a oborové didaktiky, včetně základů pedagogického výzkumu. Jejich aktivní zapojení do předvýzkumu navíc umožnilo rozvíjení badatelských kompetencí a mnohé $\mathrm{z}$ nich motivovalo $\mathrm{k}$ participaci $\mathrm{v}$ dalších fázích projektu, tentokrát již v roli pomocných výzkumníků.

Zkoumaný vzorek testovaných studentů zahrnoval 23 vysokoškolských posluchačù učitelských studijních programů (občanská výchova, český jazyk a literatura, výtvarná výchova ve vzájemných kombinacích a v kombinaci s jinými aprobačními obory - pedagogika, hudební výchova, výchova ke zdraví a tělesná výchova, učitelství pro 1 . stupeň ZŠ). Jednalo se o čtyři muže a 19 žen ve věku 21-24 let. Gymnázium absolvovalo $11 \mathrm{z}$ nich, 12 navštěvovalo jiný typ střední školy (SOŠ průmyslová, umělecká, hotelová, pedagogické lyceum). Všichni testovaní pocházejí z Moravskoslezského kraje.

Předvýzkum byl realizován ve třech etapách (duben, červen a ř́jjen 2014) ve výzkumné laboratoři eyetrackingu PdF OU. První etapa představovala vstupní tvorbu testu a vzájemné testování členek výzkumného týmu s cílem vytvořit základní podobu testových sad (karikatura, báseň, reprodukce kubistického obrazu) a ověřit srozumitelnost otázek a pokynů. Ve druhé a třetí etapě již byli testováni vysokoškolští studenti, v období mezi nimi došlo opět k drobným úpravám testu na základě prvotních dat získaných měřením.

6 Metoda papír a tužka. 
Testování jednoho studenta trvalo v průměru 20 minut (zahrnovalo dva samostatné testy), analýza karikatury zabrala přibližně 10 minut. $V$ úvodu obdrželi všichni studenti pokyny $\mathrm{k}$ průběhu testu. ${ }^{7}$ Bezprostředně před měřením byla provedena kalibrace očí zajištujuící co nejpřesnější elektronické snímání pohledu a byla vyhledána optimální a co nejpohodlnější poloha hlavy, aby případný diskomfort zbytečně nenarušoval prủběh měření v laboratorních podmínkách. Pro měření emocí v průběhu testování bylo využito čidlo odporu a vodivosti kůže s filtrací šumů (galvanic skin response). Toto čidlo umožňuje kupříkladu zaznamenat změny ve stresové reakci a aktivizaci pozornosti testovaných osob v určitých momentech měření (například když se na monitoru objeví otázka zjištující základní znalost a respondent si nedokáže vybavit odpověd'). Rozšiřuje také možnosti sledovat individuální rozdíly v emočních reakcích účastníků výzkumu. ${ }^{8}$

Před samotným výzkumným testem absolvoval každý student krátký test „na zkoušku“, jehož cílem bylo odbourat počáteční stres, zkoncentrovat se na měření, navyknout si na sled pokynů a textů a upřesnit př́ípadné nejasnosti.

Zohledněny byly přirozeně také etické aspekty výzkumu. Všichni testovaní podepsali poučený souhlas s měřením (informed consent), byli seznámeni s cíli a průběhem výzkumu, po jeho skončení měli možnost dozvědět se výsledky ve vztahu $\mathrm{k}$ jejich osobě a anonymně také $\mathrm{k}$ celé testované skupině. Pravidla nastavená pro průběh výzkumu byla striktně dodržena. Zajištěna je přirozeně také naprostá anonymita a maximální ochrana výzkumných dat (záznamů měření a přepisů audiozáznamů slovní interpretace) v zabezpečeném počítači s přístupem pouze pro členy výzkumného týmu.

Ve snaze posílit důvěryhodnost výzkumu byla $\mathrm{v}$ průběhu předvýzkumu uplatněna technika peer de-briefing (reflexe kolegů), výzkumný postup byl průběžně kontinuálně konzultován s ostatními výzkumnicemi a výzkumníky, kteř́i svými postřehy přispěli k úpravě testu a organizačních podmínek mezi druhou a třetí etapou předvýzkumu (červen a ř́́jen 2014). V závěru předvýzkumu byl realizován také audit kolegů (peer auditing), který napomohl rozvinout interpretaci získaných dat (blíže Švaříček \& Šed'ová et al., 2007, s. 34).

\footnotetext{
Respondenti nejsou limitováni časem, své pozorování doprovázejí volnými slovními odpověd'mi na otázky a pokyny zobrazené na monitoru, v průběhu testu není vhodné „odbíhat“ očima (např. obracet se na výzkumníka), postup k další otázce zahajují slovem „dále“.

8 Záznamy pořízené čidlem vodivosti a odporu kưže nebyly $\mathrm{v}$ rámci předvýzkumu vyhodnocovány (žádoucí je spolupráce s psychology) a byly využity pouze jako podpůrný materiál v konzultacích výzkumného týmu.
} 


\section{Výsledky předvýzkumu}

\subsection{Analýza audiozáznamu}

Transkripce audiozáznamů slovních odpovědí testovaných studentů na otázky ke karikatuře byly kódovány metodou otevřeného a axiálního kódování. Na základě analýzy kódovaných segmentů textu a vztahů mezi nimi pak byly utvořeny subkategorie a čtyři kategorie postihující základní obsahové a významové prvky a interpretační dimenze karikatury (tabulka 1). ${ }^{9}$

\section{Tabulka 1}

Návrh kategoriálního systému pro analýzu a interpretaci historické karikatury

\begin{tabular}{|c|c|c|c|}
\hline $\begin{array}{l}\text { Název } \\
\text { kategorie }\end{array}$ & $\begin{array}{l}\text { Název } \\
\text { subkategorie }\end{array}$ & $\begin{array}{l}\text { Označení } \\
\text { kategorie }\end{array}$ & Popis/obsah kategorie, příklady \\
\hline \multirow[t]{2}{*}{$\begin{array}{l}\text { Historické } \\
\text { osobnosti }\end{array}$} & $\begin{array}{l}\text { Základní } \\
\text { informace } \\
\text { o osobnostech }\end{array}$ & H01 & $\begin{array}{l}\text { jméno, země původu, politická funkce (ř́ršský } \\
\text { kancléř, předseda vlády) }\end{array}$ \\
\hline & $\begin{array}{l}\text { Popis } \\
\text { zevnějšku }\end{array}$ & $\mathrm{HO} 2$ & $\begin{array}{l}\text { individuální vzhled (knír, účes, výška a tloušt'ka } \\
\text { postavy), společenský oděv, uniforma, pokrývka } \\
\text { hlavy, boty }\end{array}$ \\
\hline \multirow[t]{3}{*}{ Symboly } & Věcné symboly & S1 & $\begin{array}{l}\text { hákový kř́íž, text smlouvy, (chybějící) židle, } \\
\text { otevřené dveře }\end{array}$ \\
\hline & $\begin{array}{l}\text { Geografické } \\
\text { symboly }\end{array}$ & S2 & mapa, glóbus \\
\hline & $\begin{array}{l}\text { Psychologické } \\
\text { symboly }\end{array}$ & S3 & $\begin{array}{l}\text { nonverbální znaky: pozice postavy (sedí, stojí), } \\
\text { vyjádření dominance - submise (založené ruce, } \\
\text { vzpřímený postoj, shrbená záda, sklopená hlava), } \\
\text { úsměv, podmračený výraz; pocity: radost, arogance, } \\
\text { pasivita, autorita, výsměch }\end{array}$ \\
\hline \multirow{4}{*}{$\begin{array}{l}\text { Historická } \\
\text { událost }\end{array}$} & Doba & HU1 & 1938, před druhou světovou válkou \\
\hline & Lokalizace & HU2 & Mnichov, Německo \\
\hline & $\begin{array}{l}\text { Označení } \\
\text { události }\end{array}$ & HU3 & $\begin{array}{l}\text { mnichovská konference, podpis mnichovské } \\
\text { dohody }\end{array}$ \\
\hline & $\begin{array}{l}\text { Ideologie } \\
\text { a politika }\end{array}$ & HU4 & $\begin{array}{l}\text { nacismus, komunismus, demokracie, } \\
\text { nacionalismus, appeasement }\end{array}$ \\
\hline \multirow[t]{2}{*}{$\begin{array}{l}\text { Širší } \\
\text { historický } \\
\text { kontext }\end{array}$} & $\begin{array}{l}\text { Význam } \\
\text { a souvislosti }\end{array}$ & HK1 & $\begin{array}{l}\text { „o nás bez nás“, globální dopad události, } \\
\text { krátkozrakost politiky appeasementu, mezinárodní } \\
\text { postavení SSSR (Stalin nebyl k jednání přizván, } \\
\text { přesto zásadním způsobem ovlivnil pozdější vývoj) }\end{array}$ \\
\hline & $\begin{array}{l}\text { Karikaturistův } \\
\text { postoj }\end{array}$ & HK2 & $\begin{array}{l}\text { ironie, souhlas/odmítnutí, nadhled, kritika politiky } \\
\text { appeasementu }\end{array}$ \\
\hline
\end{tabular}

V této fázi se jedná o první návrh kategoriálního systému, žádoucí je realizace kódování druhým kódovatelem a výpočet koeficientu Cohenova Kappa (zjištění reliability). 
Kvantifikace dat získaných audiozáznamy naznačuje významný rozdíl v kvalitě interpretace karikatury studenty (obrázek 2). V případě didakticky nestrukturované analýzy (otázka č. 1 testu) se participanti zaměřovali takřka výhradně na základní faktografické informace. Uváděli jména aktérů - nejčastěji Stalina (10) a Hitlera (9), nikdo nevyslovil jméno francouzského zástupce. Výjimečně byla zmíněna země původu. Popisu zevnějšku zobrazených postav nevěnoval pozornost žádný z testovaných. Jen ojediněle a povrchně byly pojmenovány hlavní symboly (chybějící židle, mapa Československa, bez povšimnutí zůstal glóbus), aniž by však studenti hledali jejich význam. Dobu vzniku a místo konání neurčil správně nikdo, čtyři respondenti se domnívali, že se jedná o druhou světovou válku, dva správně konstatovali, že jde o podpis mnichovské dohody.

Analýza u základního popisu obvykle skončila, studenti se nepokoušeli postihnout širší kontext historické události - souvislosti, význam a mezinárodněpolitické důsledky. Pouze dvakrát zaznělo ustálené rčení „o nás bez nás“, jednou „zaprodali nás“. Šest studentů vyjádřilo velmi obecně, že se „řešilo Československo", třikrát bylo uvedeno jednání o rozdělení Evropy. Ani jednoho účastníka výzkumu nenapadlo zamyslet se nad postojem karikaturisty, nad jeho motivací tuto karikaturu vytvořit. Testovaní věnovali analýze v průměru 37 sekund. Ukázala se tedy jakási snaha být s odpovědí „rychle hotov“, nezamýšlet se hlouběji nad obsahem historického pramene:

Tak já si myslím, že je to o tom, když se rozhodovalo o naší budoucnosti, jak nás zaprodaly ty ostatní národy. Je tam, můžu popisovat? Asi Hitler, Mussolini, já nevím, Stalin a dál nevím. Je tam česká mapa, československá teda. To je asi všechno, co vím.

Didakticky strukturovaná analýza (otázky č. 2-11 testu) oproti tomu přinesla mnohem lepší výsledky. Zatímco u obecně formulované otázky participanti přecházeli detaily a soustředili se ponejvíce na pojmenování hlavních aktérů události, dokázali nyní uvést výčet jednotlivých obrazových kódů mnohem přesvědčivěji (č. 2). Nejčastěji se pozastavili u symbolů geografických (mapa, glóbus - 30), avšak zůstalo většinou jen u pouhého označení, studenti nevysvětlovali jejich význam.

Výběrově se k významu jednoho ze symbolů, glóbusu, vztahovala otázka č. 7 . Zajímalo nás, zda zaměření výhradně na tento geografický symbol povede k postižení geopolitického významu události, což se potvrdilo - mezinárodní kontext byl opakovaně uváděn: 
Glóbus, protože je to konference, dohoda nad tím, jak to bude vypadat. Vlastně Československo, které se znázorňuje i na té mapě, a glóbus, protože Hitler měl ambice dobývat Evropu.

V kombinaci druhé (pojmenování symbolů) a páté otázky (pocity vyjádřené nonverbálními znaky) pak studenti jmenovali množství charakteristik psychologických (49), např. aroganci, odměřenost, autoritativnost, nervozitu, dominanci/submisi, nejistotu, strach, zoufalství, které dokládali vnějšími nonverbálními projevy znázorněných postav:

Hitler má ruce překřížené, takže samozřejmě $\mathrm{k}$ sobě nikoho nechce pustit a nedává znát to, co opravdu zamýšlí. Stalin se směje pod svým knírem, ve smyslu, že už prostě ví, jak to dopadne. Ti další, to je podle mě nejistota, takový možná i pocit strachu nějaký vnitřní, to tělo to trochu napovídá.

Samostatná otázka byla vztažena $\mathrm{k}$ mezinárodněpolitickému postavení Sovětského svazu. Vedle vágních odpovědí („Stalin stojí, protože nemá židli a nikdo ho nepozval"), se většina studentů pokusila vystihnout podstatu obrazové výpovědi:

Stalin nesedí, protože ve skutečnosti tam nebyl přítomen, ale už stojí v těch otevřených dveřích, což znamená, že se ho to týká nějakým způsobem. Je v té pozici, vy se domluvte, jak chcete, protože stejně to bude po mém.

Obdobný důvod vedl k formulaci otázky č. 10 (absence československého představitele). Záměrně byla zařazena až na závěr analýzy, protože částečně napovídá řešení otázek ostatních a naznačuje konkrétní historickou událost a její aktéry. Nejednou se v tomto momentě analýzy projevil tzv. aha-efekt. Participanti, kteří dosud nebyli schopni určit, že se jedná o podpis mnichovské dohody a pohybovali se v rovině nepřesných údajů („nějaká konference před, během, po skončení druhé světové války“), náhle pochopili souvislosti:

To je Mnichov? (smích)

Není zde zástupce Československa, protože to bylo, protože je to Mnichov, vlastně o nás bez nás, když se rozhodovalo o přidělení Sudet k Německu a nebyli jsme přizváni.

Výrok „o nás bez nás“ se zřejmě zapsal do povědomí studentů natolik, že ho jako odpověd’ na 10. otázku uvedla takřka polovina z oslovených (10). 
Analýza dále prokázala, že když je účastníkům výzkumu položena samostatná otázka vztahující se k intencím karikaturisty, většina z nich se o odpověd' alespoň pokusí. Mnohdy je to sice formulace nepřiliš obratná, povrchní nebo obecná - např. „ironie nějaká“, „zesměšňuje situaci“, „humorně ztvárněná realita“, „výsměch i varování", nezřídka však vede k hlubšímu zamyšlení a vyjádření smyslu celé karikatury:

Já si myslím, že nesouhlasil s tím, s tou politikou appeasementu a toho ustupování, že znázornil to, jaká chyba to ve skutečnosti byla, že i když ze začátku se Hitlerovi ustupovalo, tak stejně potom konflikt nastal. Takže nesouhlasí s tím.

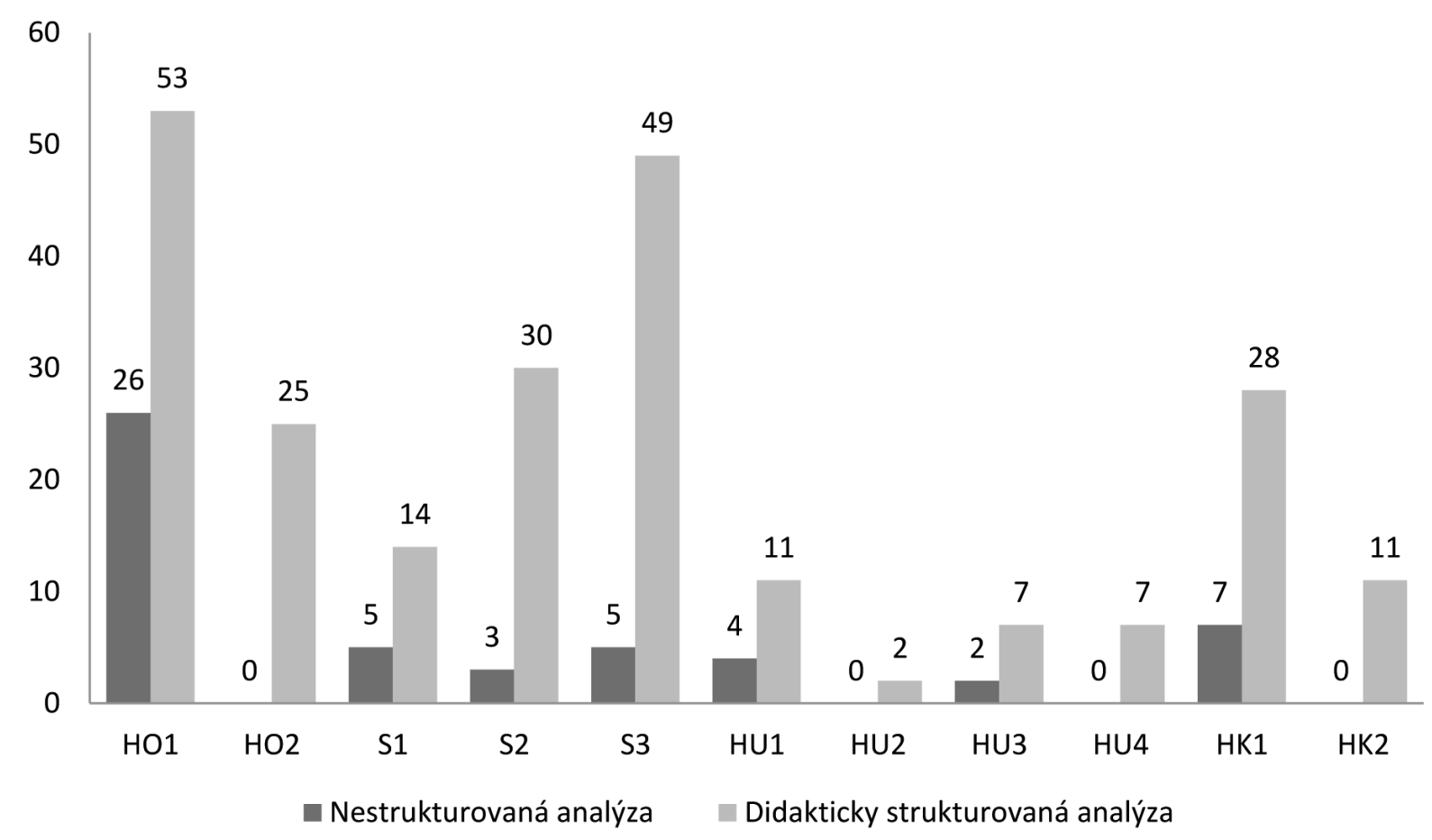

Obrázek 2. Srovnání absolutních četností - zastoupení kategorií (dle výskytu kódů) u didakticky strukturované a nestrukturované analýzy karikatury.

Pozn. Označení kategorií viz s. 285.

\subsection{Analýza vizualizovaných dat}

Analýza vizualizovaných dat prokázala podstatný rozdíl v procesu vnímání mezi strukturovanou a nestrukturovanou interpretací karikatury. Asi nejvýrazněji se to projevuje při srovnání intenzity pohledu, tedy četnosti a délky fixací u 1. a 2. otázky testu (obrázek 3). V prvním př́ípadě se studenti 
zaměřovali především na obličeje zobrazených osobností, menší počet fixací byl zaznamenán na glóbus, aniž by ho však participanti uvedli během slovní odpovědi. Zadání otázky přešli vesměs bez opakovaného čtení, což může naznačovat, že bylo dostatečně srozumitelné. Pozorněji byl čten text na karikatuře dole (Stalinův „udivený“ dotaz), avšak ve většině audiozáznamů slovní interpretace nebyl komentován a zasazen do mezinárodněpolitických souvislostí. Můžeme si povšimnout, že jednotlivé detaily (mapa Československa, text Paktu čtyř pod židlí, otevřené dveře, hákový kř́ǐ̌), byly v podstatě ignorovány.

Naproti tomu druhá otázka, vybízející k pojmenování jednotlivých symbolů, již vedla k důkladnějšímu pozorování ikonického textu. Do popředí zájmu se dostala především mapa republiky na zdi a glóbus v popředí, četné fixace jsme naměřili opět u obličejů jednotlivých aktérů, a to s patrnými rozdíly. Chamberlain a Daladier, jejichž správná identifikace činila studentům největší potíže, byli sledováni nejdéle, naopak nejmenší pozornost byla věnována Mussolinimu. Důvodem může být perspektiva, z jaké je italský představitel na karikatuře zobrazen (boční pohled). Někteří účastníci výzkumu téměř „přehlédli“ osobnost Hitlera, což může být dáno bezproblémovým rozpoznáním nacistického vůdce. Vyšší četnost fixací byla dále zjištěna u Hitlerovy paže se znakem hákového kř́žže, detailů Mussoliniho uniformy (střapce důstojnické šerpy) a textu dokumentu pod Hitlerovou židlí. Zadání otázky bylo čteno pozorněji, než u otázky předchozí, naopak text na karikatuře byl percipován s menší intenzitou (byl již studentům znám a navíc nebyl řazen mezi symboly).

V př́padě otázky č. 3 (identifikace politiků) se pohled studentů upínal téměř bez výjimky k obličejům jednotlivých postav. Slovně byli jmenováni nejčastěji Hitler (19) a Stalin (11), mnohem méně často pak Mussolini (4) a Chamberlain (2), jednou byl zmíněn Daladier. Jméno britského představitele bylo dvakrát uvedeno chybně (Churchill). U otázek č. 4 a 5 , zaměřených na nonverbální projevy a oděv, se záběr pohledu rozšíríl na celé postavy aktérů, ačkoliv také zde dominovaly fixace na tváŕích.

Při verbálním vyjádření k roli Stalina (č. 6) se pozorování koncentrovalo především na spodní část jeho obličeje (úsměv pod knírem) a dále pak na nohy ve vojenských holínkách. Sakády směřovaly také $\mathrm{k}$ obličejům dalších účastníků jednání, k textu na karikatuře a ke glóbusu. Následující otázka (č. 7) 
vztahující se k mezinárodněpolitickému významu události fixovala většinu pohledů na glóbusu, přičemž sakády vedly také k mapě a obličejům všech osobností.

Z detailů, které nebyly studentům zřejmé (č. 8), byla zjištěna největší intenzita pohledu na text Paktu čtyř pod Hitlerovou židlí, zřejmě proto, že se respondenti snažili identifikovat, o jaký dokument se jedná. Nejdéle sledovány byly dále Chamberlainovy pruhované kalhoty, střapce na Mussoliniho uniformě, autorův monogram a závěs $\mathrm{v}$ pravé části karikatury. Vizualizovaný záznam plně koresponduje se slovními odpověd’mi participantů.

Na historický kontext zaměřené otázky č. 9-11, zjištujuící znalost historické události, tehdejší mezinárodní pozice Československa a postoje karikaturisty, vedly shodně především ke sledování obličejů, mapy, textu ve spodní části karikatury, a rovněž k regresím na text zadání otázky. ${ }^{10}$

Od šestého snímku testu se projevuje zřetelný ústup od důkladného pozorování (snímek si studenti již několikrát prohlédli), což se projevuje v mnohem nižších četnostech jednotlivých fixací i v kratším čase věnovaném otázkám (tabulka 2).

Tabulka 2

Průměrný čas sledování (v sekundách) a počet fixací u jednotlivých otázek testu

\begin{tabular}{lccccccccccc}
\hline Č́́slo otázky & 1 & 2 & 3 & 4 & 5 & 6 & 7 & 8 & 9 & 10 & 11 \\
\hline $\begin{array}{l}\text { Průměrný čas } \\
\begin{array}{l}\text { Průměrný počet } \\
\text { fixaci }\end{array}\end{array}$ & 37,0 & 30,0 & 35,0 & 38,0 & 30,0 & 14,0 & 19,0 & 24,0 & 12,0 & 16,0 & 23,0 \\
\hline
\end{tabular}

V obrazovém poli karikatury bylo dále vyznačeno 26 oblastí zájmu (AOI area of interest), které se jevily z hlediska analýzy a interpretace jako podstatné. Pro tyto prvky jsme sledovali průměrný počet fixací u jednotlivých otázek testu.

10 Př́iklady výsledného zobrazení intenzity pohledu, průběhu fixací, sakád a regresí u vybraných položek testu nalezneme na obrázcích 4 a 5 . Zvoleny byly vizualizované záznamy otázek, vztahujících se detailnímu pozorování obrazu a jednotlivým symbolům. 

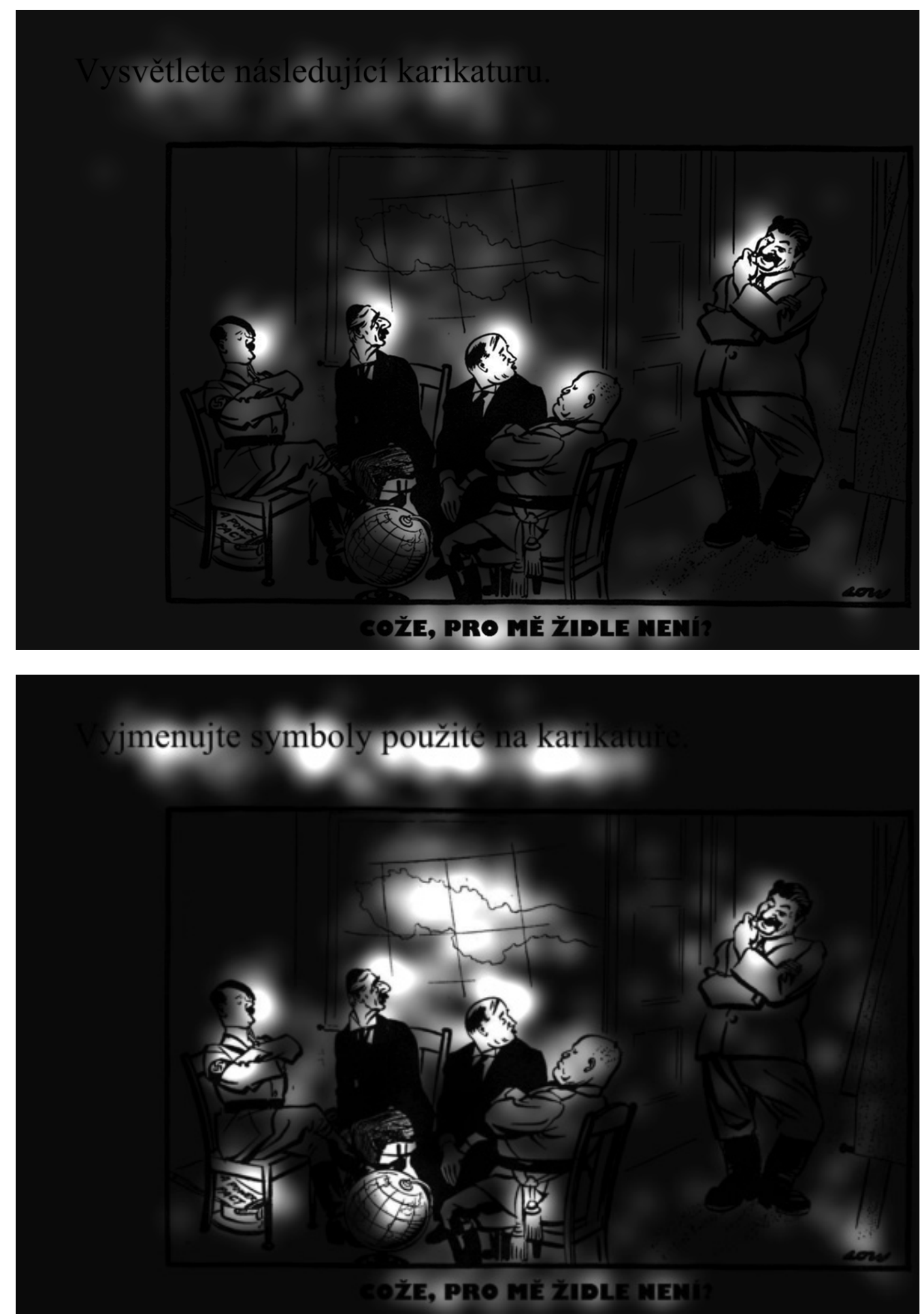

Obrázek 3. Srovnání gaze opacity map všech studentů u otázek č. 1 (nahoře) a 2 (dole).

Pozn. Barevné verze obrázků jsou dostupné v on-line archivu Pedagogické orientace na https:// journals.muni.cz/pedor. 


\section{Vyji ly $\quad$ sy na nikatuře.}

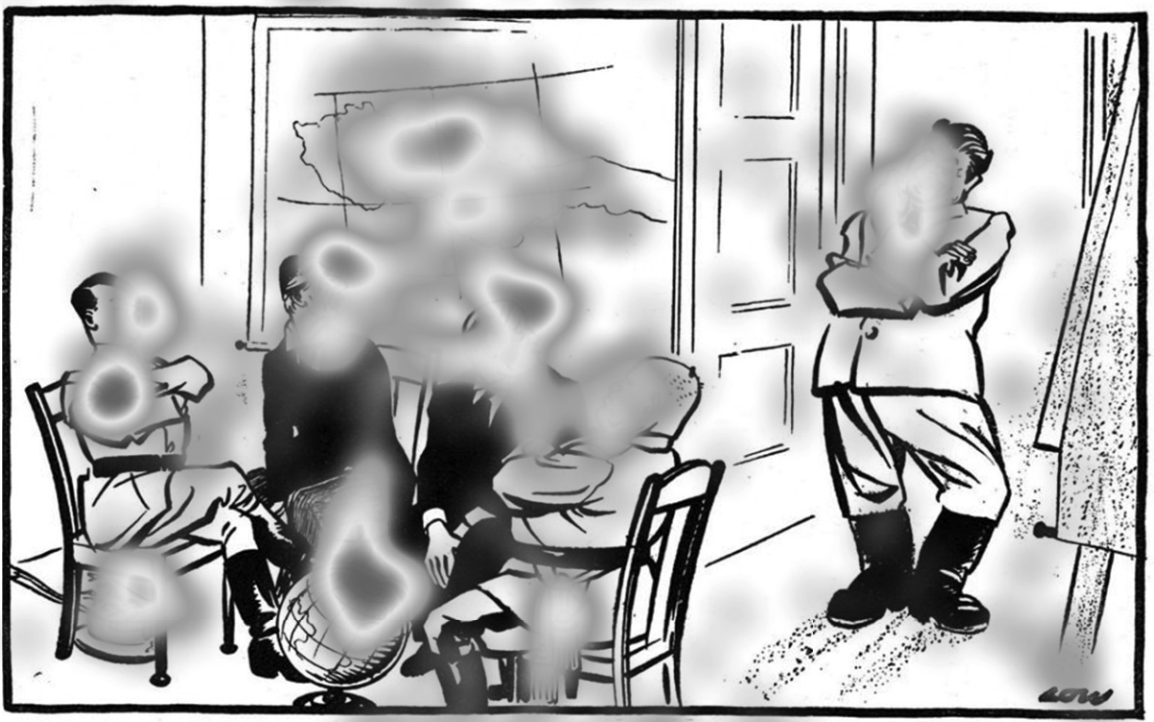

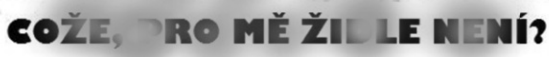

Kter' n det '1m ner rumíte?

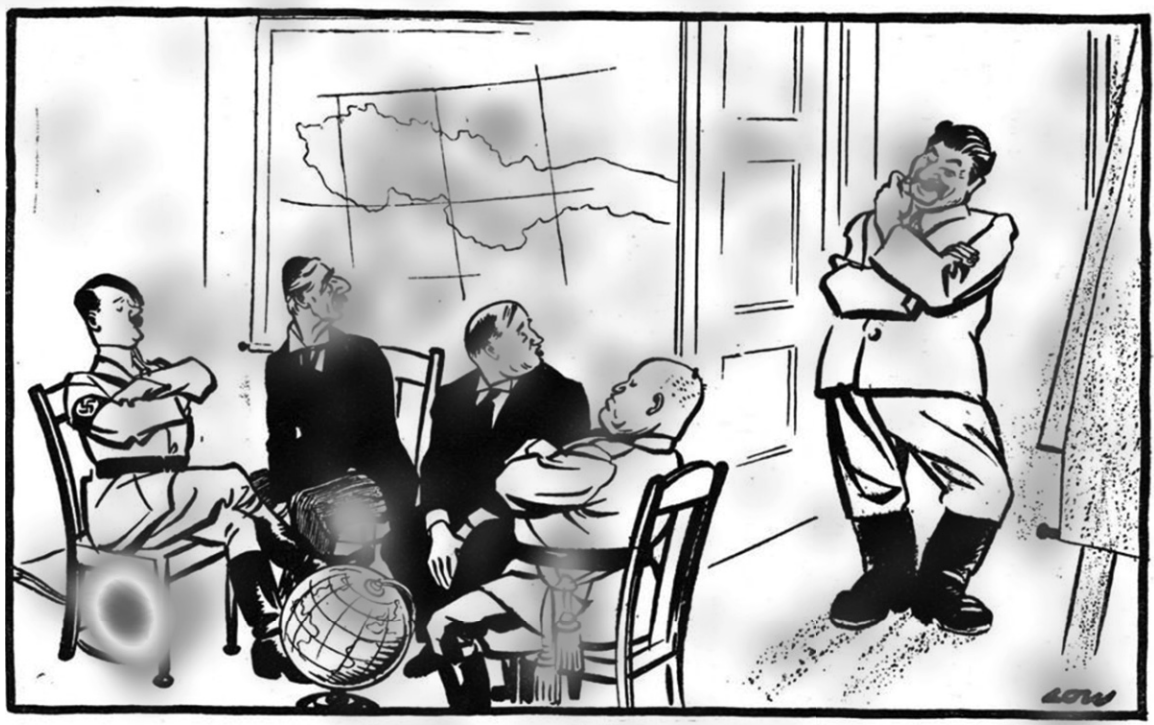

C๑ŽE, PR๑ MĚ ŽıbLE NENÍ?

Obrázek 4. Př́íklady heatmap všech studentů u otázek č. 2 (nahoře) a 8 (dole). Pozn. Barevné verze obrázků jsou dostupné v on-line archivu Pedagogické orientace na https:// journals.muni.cz/pedor. 


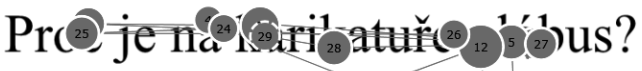

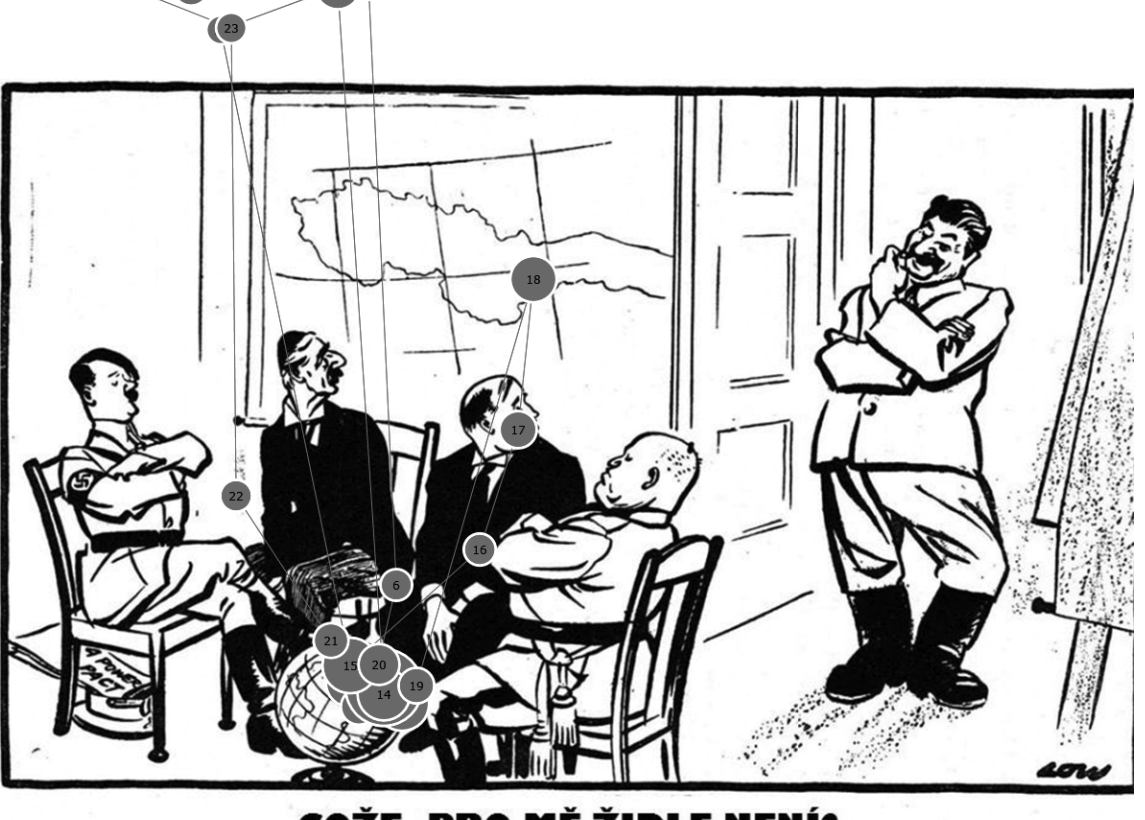

$-40$

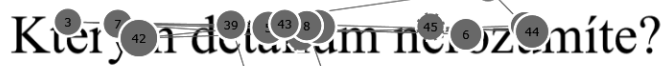

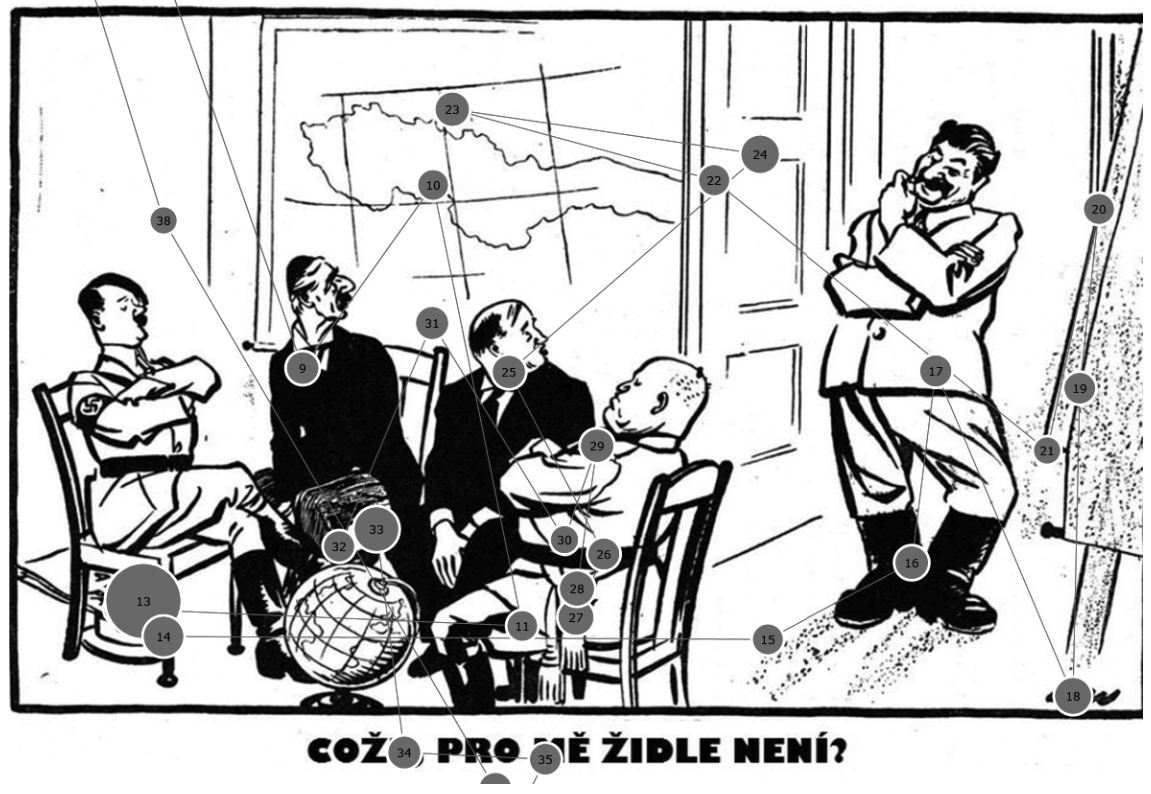

Obrázek 5. Příklady zobrazení průběhu fixací, sakád a regresí (gaze plots) jedné ze studentek u otázek č. 7 (nahoře) a 8 (dole).

Pozn. Barevné verze obrázků jsou dostupné v on-line archivu Pedagogické orientace na https:// journals.muni.cz/pedor. 
Z tabulky 3 vyplývá, že četnost očních fixací na konkrétní objekt vjemového pole souvisí s formulací otázky. U první otázky se pohled soustředil zejména na obličeje historických postav - nejvíce na Stalina, který stojí na karikatuře izolovaně a dominuje pravé části obrazu, a dále na Daladiera, u něhož si většina studentů nedokázala vybavit jméno. Naopak Hitler byl identifikován nejsnáze, proto je počet fixací výrazně nižší. Prủměrný počet fixací v případě 3. otázky, kdy bylo úkolem uvést jména jednotlivých aktérů jednání, byl nejvyšší u Daladiera a Chamberlaina. Zřetelný je také vyšší průměrný počet fixací na mapě, glóbusu a hákovém kř́ži u otázky č. 2 , která je zaměřena na výčet symbolů, a dominující pohledy na glóbus u 7. otázky. Není překvapivým zjištěním, že 8. otázka zjištující nesrozumitelné detaily vedla k fixacím právě na obtížně rozpoznatelné objekty (text Paktu čtyř, závěs, střapce Mussoliniho uniformy).

Tabulka 3

Průměrný počet fixací u vybraných prvků karikatury (vybrané otázky testu)

\begin{tabular}{lccccc}
\hline Č́́slo otázky & 1 & 2 & 3 & 7 & 8 \\
\hline Hitler & 2,6 & & 4,9 & & \\
Chamberlain & 4,4 & & 5,2 & & \\
Daladier & 5,3 & & 6,3 & & \\
Mussolini & 4,3 & & 2,7 & & \\
Stalin & 5,8 & & 2,5 & & \\
Hákový kř́ř & 1 & 2,5 & & 2,8 & \\
Mapa ČSR & 3,6 & 8,9 & & & 2,8 \\
Glóbus & 3 & 4,0 & & & 3,2 \\
Text Paktu čtyř & 4,3 & 2,5 & & & 2,4 \\
Závěs & 1 & & & & \\
Dveře & 2,9 & 2,1 & & & \\
Střapce (Mussolini) & 1,3 & & & & \\
\hline
\end{tabular}

\section{Diskuze a závěr}

Cílem předvýzkumu bylo především ověřit a optimalizovat výzkumný nástroj pro sledování procesu vnímání verbálního a ikonického textu. Výsledky ukazují, že metoda eyetracking v kombinaci s analýzou audiozáznamů může přinést cenné informace o průběhu percepce a kognice a o odlišných percepčních strategiích respondentů při analýze a interpretaci historických 
pramenů, nejen karikatur, ale také například fotografií a písemných dokumentů. Srovnání efektivity didakticky nestrukturované a strukturované analýzy historických pramenů lze považovat za smysluplný výzkumný problém, který je možno zkoumat $\mathrm{v}$ dalších fázích projektu, tentokrát již v zaměření na žáky základních a středních škol. Také smíšený design výzkumu se jeví jako optimální, nebot' umožňuje postihnout studovaný jev v celé jeho šíri a hloubce.

Ačkoliv nelze z výsledků předvýzkumu vyvozovat obecnější závěry, poukazují zjištění získaná prvotním měřením na výrazné rozdíly v kvalitě interpretace. $\mathrm{V}$ případě nestrukturované analýzy se studenti soustředili ponejvíce na rozpoznání zobrazených historických osobností (zejména na obličeje jednotlivých postav) a nevěnovali téměř žádnou pozornost důležitým symbolům a vysvětlení jejich významu. Přitom právě symboly představují samotnou podstatu karikatury jako žánru - karikaturista vystihuje komplexní společenskou situaci ve zkratce prostřednictvím užité symboliky, přičemž čerpá z kolektivního vědomí cílové skupiny, které je karikatura určena. Porozumění mechanismu vzniku tohoto typu historického pramene patří k základním kompetencím historického myšlení. Respondenti se dále nepokoušeli o postižení historického kontextu, tedy o zasazení události do mezinárodněpolitické situace (slabost politiky appeasementu, role Sovětského svazu v dalším vývoji) či o pojmenování intencí a postojů karikaturisty. Obtíže činila účastníkům výzkumu samotná identifikace konkrétní konference (omezovali se jen obecně na vztah $\mathrm{k}$ druhé světové válce).

Analýza strukturovaná prostřednictvím uceleného souboru otázek naopak vedla k mnohem hlubší interpretaci karikatury. Zobrazení gaze opacity mapy a heatmapy u druhé otázky testu ukazuje, že studenty je třeba vést zejména k překonání povrchního vnímání, k důkladnému pozorování obrazu a soustředění na detaily (jednotlivé symboly a obrazové kódy). Nonverbální komunikační znaky, které přešli respondenti v př́padě první otázky takřka bez povšimnutí, byly poměrně snadno rozeznány při zařazení páté otázky (pocity aktérů jednání). Také otázky směřované k porozumění historickému kontextu události (glóbus, stojící Stalin) vedly k relativně úspěšným odpovědím. Předvýzkum naznačuje, že studenti nejsou navyklí chápat karikaturu jako informační zdroj, jehož jedinečná hodnota spočívá ve „stranickosti“ sdělení (karikaturista zastává určitý názor a jeho cílem je přesvědčit publikum) - zatímco se tedy nad záměry autora $\mathrm{v}$ prrípadě nestrukturované analýzy 
respondenti vesměs nezamýšleli, samostatná otázka vyčleněná karikaturistovu postoji je často k pochopení hlavních intencí přivedla. Ke správnému označení mnichovské konference výrazně napomohla účastníkům výzkumu samostatná otázka na absenci československého zástupce při jednání.

Sledování očních pohybů přineslo kýžené výsledky v závislosti na konkrétní otázce. Získaná data bylo možno využít především v porovnání nestrukturované otázky („slepá místa“ v percepci obrazu jako celku) a otázek směřujících k vnímání detailů (symbolů na karikatuře, prvků, kterým respondenti nerozumějí, glóbusu reprezentujícího mezinárodní význam události). Naproti tomu u jiných otázek, u nichž participanti prokazovali základní znalosti (politické funkce, rozpoznání události jako takové), které nebylo možné z obrazu vyčíst, se pohledy koncentrovaly výhradně na postavy zobrazených osobností a nebyly zaznamenány zřetelnější odlišnosti v zaměření pohledu na další oblasti vjemového pole.

V průběhu realizace předvýzkumu vyvstaly některé podněty pro úpravu testu. Do budoucna by bylo vhodné zredukovat počet otázek tak, aby analýza nebyla ovlivněna postupným poklesem pozornosti testovaných osob. Vyřadit je možno např̀ otázku na politické funkce či oděv osobností a naopak rozšíŕit 2. otázku také o dešifrování významů jednotlivých symbolů. Žádoucí je více propojit analýzu vizualizovaných a verbálních dat (nabízí se zde důkladné zkoumání záznamů gaze replay) a důsledněji rozlišovat symboly, obrazové kódy a formální znaky. Pro hlubší uchopení problému je možné uskutečnit také retrospektivní hlasité myšlení, během něhož by participanti reflektovali vlastní průběh měření a potíže či momenty, které jim ztížily či naopak usnadnily odpovědi.

V úvahu je třeba také vzít určitý stres daný laboratorními podmínkami a př́itomností několika výzkumníků. Část participantů pocit’ovala jisté zábrany při verbální odpovědi zaznamenávané audiosystémem, někteří studenti přiznali po skončení testu stud za vlastní neznalost. Zde se nabízí prostor pro zapojení vysokoškolských studentů v roli pomocných výzkumníků, kteří by se účastnili vlastního měření.

Pracovat je nutno též s faktem, že se v průběhu měření projevila snaha účastníků výzkumu odpovídat co možná nejrychleji, což si můžeme vysvětlit jistým tlakem daným obvyklými požadavky počítačového testování v současné škole. Analýza ikonického historického pramene by však měla být časově 
omezena jen minimálně a měla by umožnit důkladné osvětlení širšího historického kontextu, vyvození ústředních intencí autora i hledání dalších otázek a možných intepretací. Výsledky předvýzkumu napovídají, že tyto kompetence je potřeba rozvíjet také $\mathrm{v}$ rámci pregraduálního studia budoucích učitelů sociálně humanitních předmětů.

\section{Poděkování}

Autorka děkuje spoluřešitelkám projektu IRP 2014 Ivaně Gejgušové a Danuši Sztablové za cennou reflexi poskytovanou v přípravné, realizační i finální fázi předvýzkumu a Liboru Jedličkovi za zpracování dat pořízených přístrojem eyetracker.

\section{Literatura}

Bartfai, A., Levander, S. E., Nybäck, H., Berggren, B. M., \& Schalling, D. (1985). Smooth pursuit eye tracking, neuropsychological test performance, and computed tomography in schizophrenia. Psychiatry Research, 15(1), 49-62.

Beers, F. B., Quinlan, T., \& Harbaugh, A. T. (2010). Adolescent students' reading during writing behaviors and relationships with text quality: An eyetracking study. Reading and Writing, 23(7), 743-775.

Błasiak W., Godlewska, M., Rosiek, R., \& Wcisło, D. (2013, v tisku). Eye tracking in physics teaching. In L'. Zelenický (Ed.), Physics teaching in reformed system of education. Nitra: Univerzita Konštanína Filozofa v Nitre.

Darrelmann B., Richard G., \& Schwartz R. (2010). Blickbewegungsmuster erfahrener und unerfahrener Fahrer im Automobilsport. Der Ophthalmologe, 107(2), 136-142.

Duchowski, A. T. (2007). Eye tracking methodology, theory and practice. Clemson: Springer.

Červenková, I., Malčík, M., Guziur, J., \& Sikorová, Z. (2014). Executive functions in comprehending the content of visual and textual information. In Proceedings information and communication technology in education (s. 53-60). Ostrava: Ostravská univerzita v Ostravě.

Franco-Watkins, A. M., \& Johnson, J. G. (2011). Decision moving window: Using interactive eye tracking to examine decission proces. Behavior Research Methods, 43(3), 853-863.

Gejgušová, I. (2014). Využití poznatků o vizuální percepci verbálních a neverbálních textů ve výuce literatury na základní škole. Slovo a obraz v komunikaci s dětmi, 4(1), 40-54.

Gläser, E., \& Becher, A. (2012). Historisches Denken und Kompetenzentwicklung im Übergang vom Elementar-zum Primarbereich. In Grundlegende Bildung ohne Brüche (s. 87-90). Wiesbaden: VS Verlag für Sozialwissenschaften.

Gracová, B. (2008). Poznatky z Výzkumu aktuální podoby výuky dějepisu na základních a středních školách. In Historie a škola VI. Klíčové kompetence a současný stav vzdělávání $v$ dějepise (s. 9-30). Praha: MŠMT.

Gracová, B. (2012). Karikatura jako zdroj paměti událostí a osobností totalitních režimů. (Výsledky empirických šetření u studující mládeže z let 2005-2001). Sborník prací Masarykovy univerzity, řada společenských věd. 26(2), 217-333. 
Gracová, B., Drahošová, L, \& Labisch, M. (2009). Metodika výuky historie na 2. stupni základních škol a středních školách z pohledu pedagogické praxe náměty pro začínajícího učitele. Ostrava: Ostravská univerzita v Ostravě.

Handro, S. \& Schönemann, B. (Eds.). (2011). Visualität und Geschichte. Münster: LIT Verlag. Henke-Bockschatz, G. (Ed.). (2000). Lernbox Geschichte: Das Methodenhandbuch. Seelze/Velber: Friedrich.

Jacob, R. J., \& Karn, K. S. (2003). Eye tracking in human-computer interaction and usability research: Ready to deliver the promises. Mind, 2(3). Dostupné $\mathrm{z}$ http://staffhome.ecm.uwa. edu.au/ 00014742/research/projectsbiblio/10.1.1.100.445.pdf

Jamet, E. (2014). An eye-tracking study of cueing effect in multimedia learning. Computers in Human Behavior, 32(March), 47-53.

Jošt, J. (2011). Čtení a dyslexie. Praha: Grada Publishing.

Jošt J. (2009). Oční pohyby, čtení a dyslexie. Praha: Fortuna.

Just, M. A., \& Carpenter, P. A. (1976). The role of eye-fixation research in cognitive psychology. Behavior Research Methods \& Instrumentation, 8(2), 139-143.

Klimeš, J. (2001). Oční kamera v marketingovém výzkumu. Strategie, 9, 32-34.

Knight, B. A., \& Horsley, M. (2014, v tisku). A new approach to cognitive metrics: Analysing the visual mechanics of comprehension using eye tracking data in student completion of high stakes testing evaluation. In M. Horsley, M. Eliot, B. A. Knight, \& R. Reilly (Eds.), Current trends in eye tracking research (s. 355-367). Berlin: Springer.

Körber, A., Schreiber, W., \& Schöner, A. (Eds.). (2007). Kompetenzen historischen Denkens: Ein Strukturmodell als Beitrag zu Kompetenzorientierung in der Geschichtsdidaktik. Neuried: Verlag ars una.

Kratochvíl, V. (2004). Modely na rozvíjanie kompetencií žiakov: k transformácii vzt'ahu histórie a školského dejepisu. Bratislava: Stimul.

Labischová, D. (2008). Didaktická média ve výuce dějepisu. Ostrava: Ostravská univerzita $\mathrm{v}$ Ostravě.

Labischová, D. (2009). Vybraná didaktická média a jejich místo ve výuce dějepisu. In Z. Beneš, B. Gracová, \& J. Průcha (Eds.), Sondy a analýzy. Učebnice dějepisu - teorie a multikulturní aspekty edukačního média (s. 45-52). Praha: MŠMT.

Labischová, D. (2014). Badatelsky orientovaná výuka - základní paradigma pro tvorbu moderní učebnice dějepisu. Sborník prací Pedagogické fakulty Masarykovy univerzity, r̆ada společenských věd, 28(2), 110-127.

Lai, M.-L., Tsai, M.-L., Yang, F.-Y., Hsu, C.-Y., Liu, T.-C., Lee, S. W.-Y. ... Tsai, C.-C. (2013). A review of using eye-tracking technology in exploring learning from 2000 to 2012. Educational Research Review, 10, 90-115.

Land, K., \& Pandel, H. J. (2008). Bildinterpretation: Die Bildquelle im Geschichtsunterricht. 1. Bildinterpretation. Schwalbach/Ts.: Wochenschau Verlag.

Lange, K. (2011). Historisches Bildverstehen oder Wie lernen Schüler mit Bildquellen? Ein Beitrag zur geschichtsdidaktischen Lehr-Lern-Forschung . Münster: LIT Verlag.

Majaranta, P., Aoki, H., Donegan, M., Hansen, D., Hansen, J., Hyrskykari, A., \& Räihä, K. (2012). Gaze interactions and applications of eye tracking. Advances in assistive technologies. Hershey: IGI Global. 
Metelková Svobodová, R. (2014). Strategie budování čtenářské gramotnosti žáků mladšího školního věku při výuce češtiny. In Národní testování a mezinárodní výzkumy výsledků vzdělávání (s. 76-97). Ostrava: Ostravská univerzita v Ostravě.

Pandel, H. J., \& Schneider G. (2005). Handbuch Medien im Geschichtesunterricht. Schwalbach/Ts.: Wochenschau Verlag.

Pandel, H. J., Becher, U. A., \& Schneider, G. (Eds.). (2002). Handbuch Medien im Geschichtsunterricht. Schwalbach/Ts.: Wochenschau Verlag.

Panofsky, E. (1978). Sinn und Deutung in der bildenden Kunst. Köln: DuMont.

Persaud, N., \& Eliot, M. (2014, v tisku). The development and refinement of student selfregulatory strategies in online learning environments. In M. Horsley, M. Eliot, B. A. Knight, \& R. Reilly (Eds.), Current trends in eye tracking research (s. 391-405). Berlin: Springer.

Popelka, S., Brychtová, A., \& Voženílek, V. (2012). Eye-tracking a jeho využití při hodnocení map. Geografický časopis, 74(1), 71-87.

Sauer, M. (2013). Beschreiben - Benennen - Deuten. Vom Wahrnehmen zum Verstehen aus kunstwissenschaftlicher Sicht. Dostupné $\mathrm{z}$ http://archiv.ub.uni-heidelberg.de/ artdok/2316/1/Sauer_Beschreiben_Benennen_Deuten_Vom_Wahrnehmen_zum_ Verstehen_2013.pdf

Sauer, M. (2000). Bilder im Geschichtsunterricht - Typen - Interpretationsmethoden, Unterrichts verfahren. Seelze: Kallmeyer-Verlag.

Schnakenberg, U. (2012). Die Karikatur im Geschichtsunterricht. Schwalbach/Ts.: Wochenschau Verlag.

Schreiber, W. (2008). Ein Kompetenz-Strukturmodell historischen Denkens. Zeitschrift für Pädagogik, 54(2), 198-212.

Schreiber, W., Körber, A., von Borries, B., Krammer, R., Leutner-Ramme, S., Mebus, S., ... Ziegler, B. (2006). Historisches Denken: Ein Kompetenz-Strukturmodell. Neuried: ars una.

Silberer, G. (2005). Die videogestützte Rekonstruktion kognitiver Prozesse beim Ladenbesuch. Marketing: Zeitschrift für Forschung und Praxis, 27(4), 263-271.

Spieß, C. (2014). Quellenarbeit im Geschichtsunterricht: Die empirische Rekonstruktion von Kompetenzerwerb im Umgang mit Quellen. Göttingen: Vandenhoeck \& Ruprecht.

Stradling, R. (2004). Multiperspektivita ve vyučování dějepisu: př́ručka pro učitele. Rada Evropy, Praha: MŠMT.

Špakov, O., \& Miniotas, D. (2007). Visualization of eye gaze data using heat maps. Electronics and electrical engineering, 74(2), 55-58.

Švaříček R., \& Šed’ová, K., et al. (2007). Kvalitativní výzkum v pedagogických vědách. Praha: Portál.

Talkenberger, H. (1994). Von der Illustration zur Interpretation: Das Bild als Historische Quelle. Methodische Überlegungen zur Historischen Bildkunde. Zeitschrift für Historische Forschung, 21(3), 289-314.

\section{Autorka}

PhDr. Denisa Labischová, Ph.D., Ostravská univerzita v Ostravě, Pedagogická fakulta, Katedra výchovy k občanství, Fráni Šrámka 3, 70900 Ostrava - Mariánské Hory, e-mail: Denisa.Labischova@osu.cz 


\section{Possibilities of using eye tracking method in the research of historical thinking competencies based on the example of historical cartoon analysis}

Abstract: The empirical study focuses on perspectives in using eyetracking method which is based on tracking eye movements in the process of visual perception of verbal or iconic text and presents the results of a pilot study carried out in 2014. The aim was to test adequacy of research instrument to find out how a particular way of structural analysis of historical cartoon influences the quality of information produced by respondents in the process of its interpretation. Theoretical background is presented in the first chapter (the meaning of historical sources in the process of the development of historical thinking competence) and eyetracking possibilities in pedagogical research are outlined. Methods of data collection and their processing are described in the second chapter. Mixed research method was used, including audiorecording analysis of students' verbal answers and statistic and visualized data processed by electronic measurement. 23 university students from the Moravian-Silesian region were used as a sample. Research results are presented in the third chapter - a suggestion of categorial system for cartoon interpretation, data visualization in heatmaps, gaze opacity maps a gaze plots and the most important quantitative data (differences in frequency and length of eye fixations during the test). Pilot study has shown that eyetracking can provide information about perception strategies applied in text interpretation, which may hardly be detected by other methods of research. The results indicate that respondents reach higher level of interpretation in case of structural analysis of historical cartoon than in case of unstructured analysis, in which verbal answers were limited to displayed personalities; important symbols, picture codes and wider historical context were neglected.

Keywords: history didactics, empirical research, historical thinking competence, historical cartoon analysis, eyetracking method, audiorecording analysis

Průcha, J. (2015). Česká vzdělanost. Multidisciplinární pohled na fenomén národní kultury. Praha: Wolters Kluwer.

Monografie se zabývá fenoménem „národní vzdělanost“, který je sice často pojednáván $\mathrm{v}$ médiích i odborných textech, ale zůstává nedefinován a neobjasněn. Autor dokládá, že k tomuto objasnění nedostačují pouze pedagogické přístupy, které se omezují na pojetí vzdělanosti jen jako produktu formálního (školního) vzdělávání. Je nutno využívat i poznatky a data historiografie, demografie, andragogiky, sociologie, ekonomie a interkulturní psychologie, jež jsou v knize vysvětleny. Jsou zařazeny také dvě případové studie - vzdělanost v USA a vzdělanost ve Finsku - na nichž se demonstruje vliv národních kultur na vzdělanost populací. Celkově směřuje kniha proti často se vyskytujícím diletantským tvrzením v médiích o údajném zaostávání či úpadku české vzdělanosti. 